\title{
The Impacts of Empowerment on the Teamwork Performance: Evidence from Commercial Banks in Vietnam
}

\author{
Van Dung HA* \\ R eceived: February 3, 2020 Revised: February 24, 2020 Accepted: March 1, 2020.
}

\begin{abstract}
The research examines the impacts of empowering leadership on teamwork performance of the employees in sales departments at commercial banks in Vietnam. Based on the data from the sample survey of 406 employees in sales departments of commercial banks in Vietnam, the paper uses various types of statistical methods and assesses the reliability of scales with Cronbach's Alpha, Confirmatory Factor Analysis as well as Structural Equation Modeling for analysis. The results show that the Empowering Leadership factor has a directly positive impact on Knowledge Sharing and Teamwork Performance, which means when the Empowering Leadership is positive, the Knowledge Sharing and Teamwork Performance will increase. In addition, Empowering Leadership also has an indirect impact on Teamwork Performance through Knowledge Sharing factor, which means when the Empowering Leadership is positive, the Teamwork Performance will increase. Moreover, Knowledge Sharing factor has a directly positive impact on Teamwork Performance, which means when the Knowledge Sharing factor is positive, the Teamwork Performance will increase. The findings suggest that Empowering Leadership has both directly and indirectly positive influence on Teamwork Performance. Moreover, Empowering leadership has a directly positive impact on Knowledge-sharing while Knowledge-sharing has a directly positive impact on Teamwork Performance of sales departments of commercial banks in Vietnam.
\end{abstract}

Keywords : Leadership, Empowerment, Reliability, Teamwork, Commercial Banks, Vietnam

JEL Classification Code: C31, D22, M54

\section{Introduction}

How to make the employees have their rights of autonomy and self-determination at work is significantly important, which promotes the spirits of self-conscious and initiative in problem-solving for the matters arising at work and decision-makings of the employees in order to meet the urgent needs of the works for the demands from their customers (Tung \& Chang, 2011).

Thus, the issues of empowering leadership are increasingly concerned and stated in most of the studies on

*First Author and Corresponding Author. Institute for Banking Science and Technology Research, Banking University Ho Chi Minh City, Vietnam [Postal Address: 39 Ham Nghi Street, District 1, Ho Chi Minh City, 70000, Vietnam] Tel. +84 983355 446,

Email: dunghv@buh.edu.vn

(c) Copyright: The Author(s)

This is an Open Access article distributed under the terms of the Creative Commons Attribution Non-Commercial License (http://Creativecommons.org/licenses/by-nc/4.0/) which permits unrestricted noncommercial use, distribution, and reproduction in any medium, provided the original work is properly cited. leadership. Most typically were the studies conducted by Ahearne, Mathieu, and Rapp (2005), Zhang and Bartol (2010), Tung and Chang (2011) and most recently, Kundu, Kumar, and Gahlawat (2019). As can be seen in these studies, it has shown that the positive role of empowering leadership in an organization's activities, which stimulates the improvement of teamwork performance and increase in work outcomes. These research results have contributed a great deal in searching for a number of directions for improving the existing ineffective teamwork conditions of some organizations.

Based on the background stated above, the objectives of this article are to identify the effects of Empowering Leadership on the Teamwork Performance of sales departments at commercial banks in Vietnam. Based on the findings, the study has proposed some governance implications to improve the Teamwork Performance of the employees in sales departments at commercial banks in Vietnam. 


\section{Literature Review}

\subsection{Concept of Empowering Leadership (EL)}

Empowerment is not simply defined as the practice of sharing the authority of a leader. EL is construed that an individual is empowered by the leader and has high autonomy to perform the duties and these duties are considered as meaningful duties and make some impacts on the work, resulting into higher outcomes in their works (Kirkman \& Rosen, 1999). Tung and Chang (2011) explained that the autonomy at work and the selfdetermination gained from EL had some positive impacts on job performance. The employees who are empowered the leadership are self-managed to gain higher cognitive psychology in working. Meanwhile, the EL is also defined as a process of fulfilling the conditions for sharing the power with the employees by allocating the importance of their work, giving the autonomy in decision-makings, showing their trust in the capacities of the employees, and eliminating the obstacles to work outcomes (Zhang \& Bartol, 2010). Moreover, the EL, as well as building leadership exchanges between the members, are based on the theory of the ideas of linking between the leaders and the employees (Zhang \& Bartol, 2010).

\subsection{Concept of Teamwork and Teamwork Performance (TP)}

Teamwork means as a combination of both physical and mental strength of members of the same group together, they are willing to sacrifice personal interests to achieve the group's common goals (Podsakoff, MacKenzie, Lee, \& Podsakoff, 2003). Therefore, the TP is reflected in the team members' willingness to share difficulties and help each other while working; above all it is the goal of the group to meet the overall needs and goals of the organization's work (Podsakoff et al., 2003).

\subsection{Research Hypotheses}

\subsubsection{Relationship between Empowering Leadership and Teamwork Performance (TP)}

EL is posed as a matter the levels of sharing the authority rather than the work situation. This is what the managers need to make their judgments regarding whom and to what extent the empowerment shall be shared (Ford \& Fottler, 1995). Empowerment can be considered effective if there are good outcomes between the leaders and their subordinates (Tung \& Chang, 2011). When employees have more autonomy in their work, it helps to improve their TP (Yukl \& Fu, 1999). In addition, TP also requires the interaction and cooperation between the members and the ultimate team goals cannot be achieved unless all members are non-cooperative and interacting on duty (Wageman, 1995). Consequently, EL may be beneficial to teamwork outcomes by encouraging the team members to proactively solve their problems, speeding up the responses of the team members, and improving the working quality with the team members (Cohen \& Bailey, 1997). Therefore, the research hypotheses are proposed as follows:

H1: Empowering leadership has a positive and direct impact on teamwork performance.

\subsubsection{Relationship between Empowering Leadership (EL) and Knowledge Sharing (KS)}

In order to develop this relationship, it is necessary to understand what $\mathrm{KS}$ is defined. KS refers to providing task information and know-how to help others and collaborate with others to solve problems, develop new ideas, or perform the policies or procedures. (Wang \& Noe, 2010). KS means as an activity which knowledge (specifically, information, skills or expertise) is exchanged among the people, friends, family, communities or organizations (Serban, Zuraini, \& Aris, 2002; Hasmath \& Hsu, 2016).

Emotional, behavioral, and cognitive aspects are considered to be the characteristics of an effective teamwork (Ilgen, Hollenbeck, Johnson, \& Jundt, 2005). Srivastava, Bartol, and Locke (2006) introduced KS among team members as a way to share their ideas, information, and suggestions related to work tasks with each other. This helps to store and increase the knowledge among team members (Liebowitz, 1999; Purnomo, Rahayu, Riani, Suminah, \& Udin, 2020).

The problem of knowledge sharing does not occur naturally among the team members, but it requires the rights of the team members (Tung \& Chang, 2011). Therefore, an important potential benefit of EL is to facilitate for KS among team members and to build up team performance (Srivastava et al., 2006). The decision-making and coaching behaviors with the participations of the leaders also help to ensure that the team members achieve fairness at work and motivate the employees to contribute their ideas and work information (Tung \& Chang, 2011). The EL encourages employees to work in groups, thereby, creating the opportunities for knowledge sharing (Arnold, Arad, Rhoades, \& Drasgow, 2000). Therefore, the research hypotheses are given as follows:

H2: Empowering leadership has a directly positive impact on knowledge sharing among the team members.

\subsubsection{Relationship between Knowledge Sharing (KS) and Teamwork Performance (TP)}


The KS within the team allows to perform the tasks and coordinate to work among team members, motivating to get greater TP (Stasser \& Titus, 1985). Smith-Jentsch et al. (2005) demonstrated that KS had a positive impact on TP, which in turn promotes firm efficiency (Rahman, Meah, \& Chaudhory, 2019; Ha, 2020). The interactions among team members on sharing the problems, information, and job knowledge with each other are prerequisites for increasing TP (Srivastava et al., 2006). Therefore, the research hypotheses are proposed as follows:

H3: Knowledge sharing among team members has a direct impact on team performance.

\subsubsection{Mediating role of Knowledge Sharing (KS)}

Ahearne et al. (2005) have shown that KS is the mediator for the impact of EL on TP. The effective sharing and use of knowledge are depended on the teamwork capabilities in creating and combining the knowledge of each member (Srivastava et al., 2006). The process of EL may be able to give each member the common power by identifying the importance of their work, showing their trust in the members' capabilities, and leading to higher TP (Arnold et al., 2000) or welfare (Purwanti, Susilo, \& Indrayani, 2020). The team members may become more willing to take their risks in sharing and exchanging the knowledge when empowering leadership. The effectiveness of EL is illustrated the greater TP if the team members increase KS (Srivastava et al., 2006). Thus, the research hypotheses are given as follows:

H4: Knowledge sharing plays as the mediator for the positive impact of empowering leadership on teamwork performance.

\section{Research Methods and Materials}

The paper methodology is as follows:

Qualitative method: First, the author conducts research, and synthesizes theories as well as previous literature relating to the research topic. Next, the author conducts discussions with 09 sales experts in banking industry to adjust the observed variables of the factors in the proposed research model.

Quantitative method: Data collected from direct consultation with employees in sales departments at commercial banks in Vietnam. The convenient sampling method is employed to form the sample size of 406 employees working at sales departments of commercial banks in Vietnam. Basic analytical techniques (statistics, Cronbach's alpha, EFA, CFA, and SEM) are conducted by both SPSS 20 and AMOS 20 software to demonstrate the impacts of empowering leadership on the team performance of sales departments at commercial banks in Vietnam (see Table 1).

Table 1: Measurement scales for the factors

\begin{tabular}{|c|c|c|}
\hline Factor & Encryption & Measurement scale \\
\hline \multirow{4}{*}{$\begin{array}{c}\text { Empowering } \\
\text { leadership (EL) } \\
\text { Ahearne et al. } \\
\quad(2005)\end{array}$} & EL1 & $\begin{array}{c}\text { Are you motivated into the organization's } \\
\text { decision-making process? }\end{array}$ \\
\hline & EL2 & $\begin{array}{c}\text { Are you expressed your confidence in } \\
\text { your work? }\end{array}$ \\
\hline & EL3 & $\begin{array}{l}\text { Do you realize the importance of the } \\
\text { work that you are doing? }\end{array}$ \\
\hline & EL4 & $\begin{array}{l}\text { Do you have the autonomy in the work } \\
\text { that you are assigned? }\end{array}$ \\
\hline \multirow{4}{*}{$\begin{array}{l}\text { Knowledge } \\
\text { sharing (KS) } \\
\text { Yoo et al. } \\
(2002)\end{array}$} & $\mathrm{KS} 1$ & $\begin{array}{l}\text { Do you often share your knowledge wi } \\
\text { th others in the organization? }\end{array}$ \\
\hline & $\mathrm{KS} 2$ & $\begin{array}{c}\text { Are you one of the more active contri } \\
\text { butors than others in the organization i } \\
n \text { knowledge sharing? }\end{array}$ \\
\hline & KS3 & $\begin{array}{l}\text { Do you make an effort to spend your } \\
\text { time participating in activities that cont } \\
\text { ribute knowledge to the organization? }\end{array}$ \\
\hline & KS4 & $\begin{array}{c}\text { Do you try to share your knowledge w } \\
\text { ith the organization? }\end{array}$ \\
\hline \multirow{4}{*}{$\begin{array}{c}\text { Teamwork } \\
\text { performance } \\
(\mathrm{TP}) \\
\text { Podsakoff et al. } \\
(2003)\end{array}$} & TP1 & $\begin{array}{l}\text { Do your team members often discuss their } \\
\text { issues when working together? }\end{array}$ \\
\hline & TP2 & $\begin{array}{l}\text { Do your team members often help and } \\
\text { support each other when working? }\end{array}$ \\
\hline & ТP3 & $\begin{array}{l}\text { Does your team always have a common } \\
\text { goal when working? }\end{array}$ \\
\hline & TP4 & $\begin{array}{l}\text { Are your teamwork goals always related to } \\
\text { the work at the organization? }\end{array}$ \\
\hline
\end{tabular}

Table 2: Descriptive statistics

\begin{tabular}{|c|c|c|c|}
\hline Variable & & Frequency (n) & Percent (\%) \\
\hline \multirow{2}{*}{ Gender } & Male & 218 & 53.7 \\
\hline & Female & 188 & 46.3 \\
\hline \multirow{3}{*}{ Education } & College or lower & 27 & 6.7 \\
\hline & University & 248 & 61.1 \\
\hline & Postgraduate & 131 & 32.3 \\
\hline \multirow{4}{*}{ Age } & $<30$ & 65 & 16.0 \\
\hline & $30-40$ & 157 & 38.7 \\
\hline & $41-50$ & 136 & 33.5 \\
\hline & $>50$ & 48 & 11.8 \\
\hline \multirow{3}{*}{ Income } & $\begin{array}{l}<5000000 \\
\mathrm{VND} / \text { month }\end{array}$ & 62 & 15.3 \\
\hline & $\begin{array}{l}5-10000000 \\
\text { VND/month }\end{array}$ & 246 & 60.6 \\
\hline & $\begin{array}{l}>10000000 \\
\mathrm{VND} / \text { month }\end{array}$ & 98 & 24.1 \\
\hline
\end{tabular}


It is necessary to investigate the number of samples 5 times as the same as the number of variables (Hoang \& Chu, 2008). Thus, the minimum observations in this study will be: $5 \times 12=60$ observed variables. However, in order to ensure representativeness of the sample, the author surveys 450 salespeople, which give 406 valid questionnaires.

There are $46.3 \%$ female employees and $53.7 \%$ male employees in the sample. Educational qualifications are mainly at university level, accounting for $61.1 \%$. The main age group from 30 to 50 years old accounts for $72.2 \%$. The highest proposition of average income ranges from VND 5 million to 10 million per month with $60.6 \%$ (see Table 2).

\section{Results and Discussion}

Cronbach's alpha analysis shows that all factor coefficients have values greater than 0.8. EL (Empowering leadership), KS (Knowledge sharing), TP (Teamwork performance) have Cronbach's alpha values of $0.905,0.807$, and 0.857 , respectively. The correlation coefficient of the total variables is also greater than 0.3. Therefore, all variables are satisfactory for analyzing. Next, 12 variables belonging to factors were included in the Exploratory Factor Analysis (EFA) to explore the structure of a scale of factors: EL, KS, and TP. EFA analysis results indicate that $\mathrm{KMO}$ is 0.726 (which is greater than 0.5) while the ChiSquare statistic of Bartlett's test is 3,777.943 with significance level of 0,000 and 66 degree of freedom. Therefore, all variables are valid to include in the model analysis (see Table 3).

Table 3: Rotated Component Matrix

\begin{tabular}{|c|c|c|c|}
\hline \multirow{2}{*}{} & \multicolumn{3}{|c|}{ Component } \\
\cline { 2 - 4 } & $\mathbf{1}$ & $\mathbf{2}$ & $\mathbf{3}$ \\
\hline EL1 & 0.956 & & \\
\hline EL4 & 0.939 & & \\
\hline EL2 & 0.839 & & \\
\hline TP1 & 0.793 & & \\
\hline TP3 & & 0.968 & \\
\hline TP4 & & 0.964 & \\
\hline TP2 & & 0.751 & \\
\hline KS3 & & 0.560 & \\
\hline KS2 & & & 0.870 \\
\hline KS4 & & & 0.812 \\
\hline KS1 & \multicolumn{3}{|c|}{} \\
\hline \multicolumn{4}{|c|}{ Eigenvalue $=1.635$} \\
\hline Cumulative & $37.109 \%$ & $58.603 \%$ & $72.231 \%$ \\
\hline
\end{tabular}

The eigenvalue value is 1.653 greater than 1 and stops at the third line with the total variance extracted is $72.231 \%$ greater than $50 \%$. At the same time, all loading factors are greater than 0.6 and these factors are arranged in three different groups: EL, KS, and TP. After that, all factors are used for CFA analysis. The data achieve convergent value because in CFA results, the value of Chi-square/ $\mathrm{df}=3.295$ is smaller than 5 , GFI $=0.944>0.9$, TLI $=0.960>0.95$, $\mathrm{CFI}=0.973>0.95$ and RMSEA $=0.075<0.1$. In addition, the standardized weights are found to be greater than 0.5 . So, three main factors including EL, KS, and TP are included in the analysis (see Figure 1).

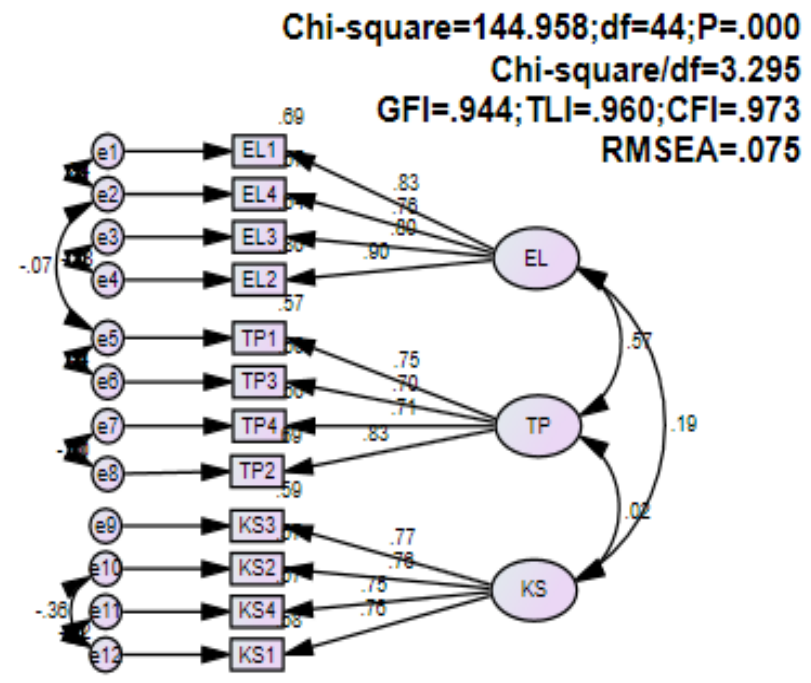

Figure 1: Standardized results of CFA

The variance extracted and composite reliability of three factors including empowering leadership, knowledge sharing, and teamwork performance show reliable results. Empowering leadership has 0.811 of variance extracted and 0.905 of composite reliability. Knowledge sharing has 0.785 of variance extracted and 0.823 of composite reliability while teamwork performance has 0.769 of variance extracted and 0.866 of composite reliability.

Table 4: SEM analysis results (standardized coefficients)

\begin{tabular}{|c|c|c|}
\hline No. & Content & Value \\
\hline 1 & Chi-square/df & 3.295 \\
\hline 2 & P-value của Chi-square & 0.000 \\
\hline 3 & GFI & 0.944 \\
\hline 4 & TLI & 0.960 \\
\hline 5 & CFI & 0.973 \\
\hline 6 & RMSEA & 0.075 \\
\hline
\end{tabular}

The discriminatory value of the concepts has been achieved because the correlation coefficients of each pair of concepts are different from 1 at significant level of $5 \%$. All 
factors also ensure the reliability since the combined reliability values as well as total variance extracted of all factors are greater than 0.5 (see Figure 4).

Some indicators such as Chi-square/df value $=3.295<5$, $\mathrm{GFI}=0.944>0.9, \mathrm{TLI}=0.960>0.95, \mathrm{CFI}=0.973>0.95$ and RMSEA $=0.075<0.1$ indicate that the Structural Equation Model gives out consistent results with market data (see Figure 2).

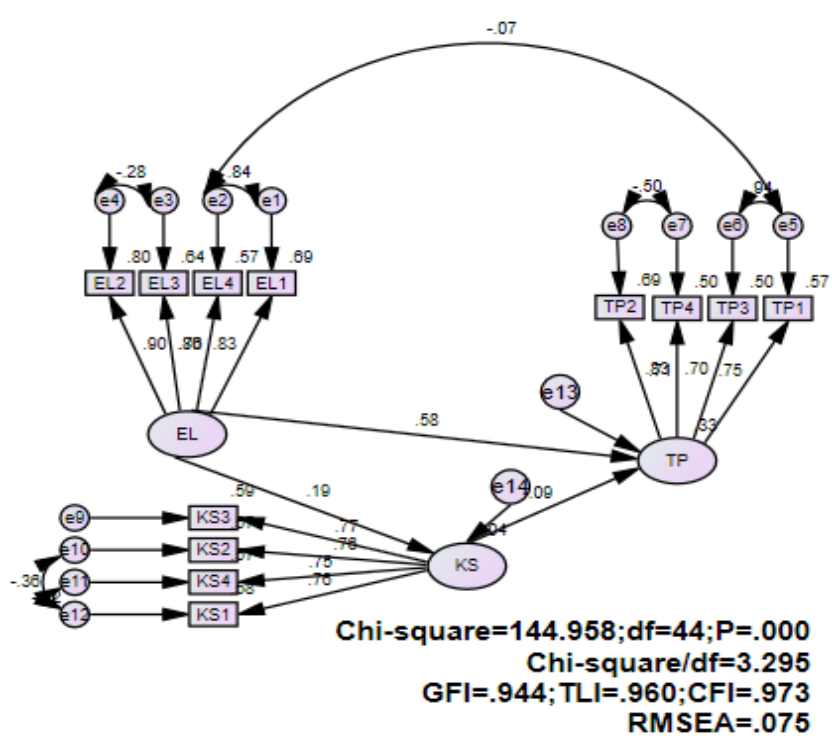

Figure 2: The impacts of empowering leadership on the team performance of the employees in sales departments at commercial banks in Vietnam

Table 5: SEM model results

\begin{tabular}{|c|c|c|c|c|c|c|}
\hline & & & Regress & coefficient & & \\
\hline & elation & & Direct & Indirect & S.E & C.K \\
\hline KS & $<---$ & EL & 0.163 & & 0.047 & 3.477 \\
\hline TP & $<---$ & EL & 0.488 & $0.015^{*}$ & 0.056 & 8.748 \\
\hline TP & $<---$ & KS & 0.090 & & 0.048 & 1.881 \\
\hline $\mathrm{TP}$ & $<---$ & EL* & & & & \\
\hline & & & P-value & $\begin{array}{l}\text { Standardize } \\
\text { d estimate }\end{array}$ & $\begin{array}{r}\text { Stand } \\
\text { esti } \\
\text { accordi } \\
\text { diag }\end{array}$ & $\begin{array}{l}\text { dized } \\
\text { ate } \\
\text { g to the } \\
\text { am }\end{array}$ \\
\hline KS & $<---$ & EL & 0.000 & 0.192 & & \\
\hline TP & $<---$ & EL & 0.000 & 0.584 & & \\
\hline TP & $<---$ & $\mathrm{KS}$ & 0.030 & 0.092 & & \\
\hline TP & $<---$ & EL* & & 0.018 & & \\
\hline
\end{tabular}

The correlations among factors EL, KS, and TP are statistically significant in SEM model. In the SEM linear structural model, the Empowering Leadership has both directly and indirectly positive impacts (through the mediator as Knowledge Sharing) to Teamwork Performance. Additionally, Empowering Leadership factor also has directly positive impact on Knowledge Sharing and Knowledge Sharing factor has directly positive impact on Team Performance (see Table 5).

The Empowering Leadership factor has a directly positive impact on Knowledge Sharing and Teamwork Performance with the coefficients of 0.19 and 0.58, respectively, which means when the Empowering Leadership is positive, the Knowledge Sharing and Teamwork Performance will increase (with the corresponding increase of one time in the Empowering Leadership, the Knowledge Sharing and Teamwork Performance will increase by 0.19 times and 0.58 times, respectively).

In addition, Empowering Leadership also has an indirect impact on Teamwork Performance through Knowledge Sharing factor with the regression coefficient of 0.02 , which means when the Empowering Leadership is positive, the Teamwork Performance will increase (with the corresponding increase of one time in the Empowering Leadership, the Teamwork Performance will increase by 0.02 times).

Moreover, Knowledge Sharing factor has a directly positive impact on Teamwork Performance with the coefficient of 0.09 , which means when the Knowledge Sharing factor is positive, the Teamwork Performance will increase (with the corresponding increase of one time in the Knowledge Sharing, the Teamwork Performance will increase by 0.09 times) (see Figure 3).

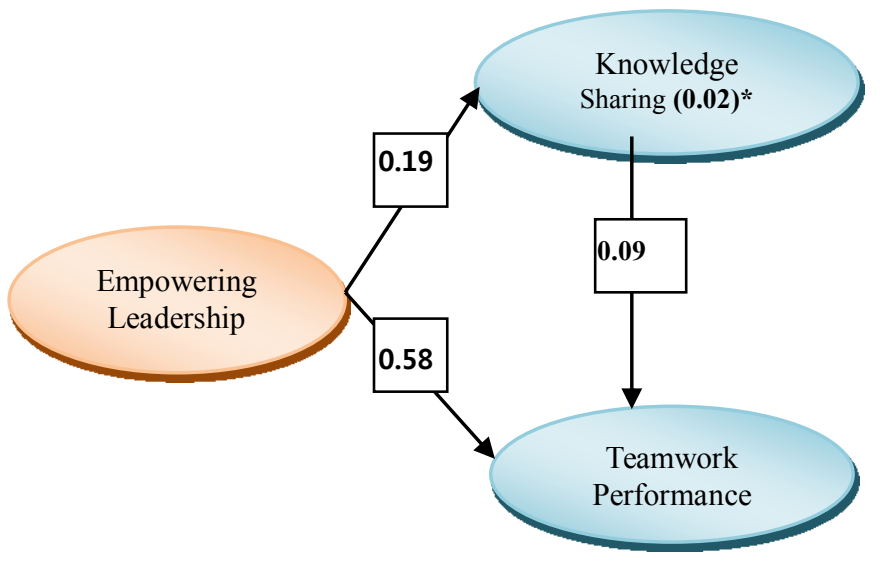

*: Demonstrating the mediating role of Knowledge Sharing in the relationship between Empowering Leadership and Teamwork Performance Figure 3: The impacts of empowering leadership on the team performance of the employees in sales departments at commercial banks in Vietnam 


\section{Implications and Conclusion}

\subsection{Policy Implications}

To increase the Teamwork Performance of sales departments in the systems of some commercial banks in Vietnam, the research has proposed a number of governance implications:

- The commercial banks ought to enhance the spirit of teamwork, collectivity to make its employees more cohesive.

- The commercial banks should diversify its forms of teamwork, actively perform knowledge sharing for all of the employees in their units.

- Not only should the commercial banks encourage its employees to support each other at work, but the employees also need to be more proactive in sharing the work that they are doing so that their colleagues know and can share their experiences to help them do their jobs better.

- The leaders must know to listen to their employees' statements, ideas, and creativities; and ask them to corporate and give their opinions on other major issues.

- The commercial banks should promulgate its legal documents regulating the right to decide on the matters related to works without consulting the senior leaders.

- It is necessary for the leaders to always support and help the employees to perform their tasks better.

Despite of making a lot of attempts to complete the study due to the limitations on time, budget, and knowledge, the paper has some limitations, i.e. the scope of the research only focuses on some commercial banks in a few of big cities of Vietnam, such as Ha Noi, Ho Chi Minh City, Da Nang City, and Can Tho City, or the sample size is relative small. Therefore, future studies may increase its sample size as well as expand the scope of the research.

\subsection{Conclusion}

Firstly, the paper proposes a research model from three factors: (1) Empowering Leadership, (2) Knowledge Sharing and (3) Teamwork Performance. Based on that, the author conducts data collection by survey for these factors. Data analysis results achieved the following results:

The study performs some statistical variables of gender, education level, age and income.

- Next, Cronbach's alpha and EFA analysis results confirm that the variables are arranged into three factors, which are EL (Empowering leadership), KS (Knowledge sharing), TP (Teamwork performance).

- The CFA and SEM linear structure model indicate: (1) Empowering Leadership factor has positive impacts both directly and indirectly (through the mediator as Knowledge Sharing) to Teamwork Performance; (2) Empowering
Leadership factor also has directly positive impact on Knowledge Sharing and (3) Knowledge Sharing factor has directly positive impact on Team Performance.

\section{References}

Ahearne, M., Mathieu, J., \& Rapp, A. (2005). To empower or not to empower your sales force? Anempirical examination of the influence of leadership empowerment behaviour on customer satisfaction and performance. Academy of Applied Psychology, 90(5), 945-955.

Arnold, J. A., Arad, S., Rhoades, J. A., \& Drasgow, F. (2000). The empowering leadership questionnaire: the construction and validation of a new scale for measuring leader behaviors. Journal of Organizational Behavior, 21(3), 249-269.

Cohen, S. G., \& Bailey, D. E. (1997). What makes teams work: group effectiveness research from the shop floor to the executive suite. Journal of Management, 23(3), 239-290. https://doi.org/10.1177/014920639702300303

Ford, R. C., \& Fottler, M. D. (1995). Empowerment: A master of Degree. Academy of Management Perspectives, 9(3), 677-692. https://doi.org/10.1108/00483480410561556

Ha, V. D. (2020). Impact of Organizational Culture on the Accounting Information System and Operational Performance of Small and Medium Sized Enterprises in Ho Chi Minh City. Journal of Asian Finance, Economics and Business, 7(2), 301 308. https://doi.org/10.13106/jafeb.2020.vol7.no2.301

Hasmath, R., \& Hsu, J. Y. J. (2016). Communities of Practice and the NGO Sector in China. Paper presented at the International Society for Third Sector Research Conference, Stockholm, Sweden.

Hoang, T., \& Chu, N. M. N. (2008). Textbook of Data Analysis with SPSS Episodes $1 \& 2$. Ho Chi Minh City, Vietnam: Hong Duc Publishing House.

Ilgen, D. R., Hollenbeck, J. R., Johnson, M., \& Jundt, D. (2005). Teams in organizations: from I-P-O models to IMOI models. In S. T. Fiske, A. E. Kasdin, \& D. L. Schacter (eds), Annual Review of Psychology (Vol. 56, pp. 485-516).

Kirkman, B. L., \& Rosen, B. (1999). Beyond self-management: antecedents and consequences of team empowerment. Academy of Management Journal, 42(1), 58-74.

Kundu, S., Kumar, S., \& Gahlawat, N. (2019). Empowering leadership and job performance: mediating role of psychological empowerment. Management Research Review, 42(5), 605-624.

Liebowitz, J. (1999). Knowledge Management Handbook. Cleveland, OH: CRC Press.

Podsakoff, P. M., MacKenzie, S. B., Lee, J. Y., \& Podsakoff, N. P. (2003). Common method biases in behavioral research: a critical review of the literature and recommended remedies. Journal of Applied Psychology, 88(5), 879-903.

Purnomo, S., Rahayu, E. S., Riani, A. L., Suminah, S., \& Udin U. (2020). Empowerment Model for Sustainable Tourism Village in an Emerging Country. Journal of Asian Finance, Economics and Business, 7(2), 261270. https://doi.org/10.13106/jafeb.2020.vol7.no2.261

Purwanti, P., Susilo, E., \& Indrayani, E. (2020). Business 
Empowerment Program and Household Economic Welfare: Lesson from Indonesia. Journal of Asian Finance, Economics and Business, 313320. https://doi.org/10.13106/jafeb.2020.vol7.no1.313

Rahman, M. M., Meah, M. R., \& Chaudhory, N. U. (2019). The Impacts of Audit Characteristics on Firm Performance: An Empirical Study from an Emerging Economy. Journal of Asian Finance, Economics and Business, 6(1), 5969. http://doi.org/10.13106/jafeb.2019.vol6.no1.59

Serban, N., Zuraini, A., \& Aris, B. Z. (2002). Requirement for knowledge sharing behavior: A review of empirical findings. Journal of Asian Scientific Research, 3(6), 517-526.

Smith-Jentsch, K. A., Mathieu, J. E., \& Kraiger, K. (2005). Investigating linear and interactive effects of shared mental models on safety and efficiency in a field setting. Journal of Applied Psychology, 90(3), 523-535.

Srivastava, A., Bartol, K. M., \& Locke, E. A. (2006). Empowering leadership in management teams: effects on knowledge sharing, efficacy, and performance. Academy of Management Journal, 49(6), 1239-1251.

Stasser, G., \& Titus, W. (1985). Pooling of unshared information in group decision making: biased information sampling during discussion. Journal of Personality and Social Psychology, 48(6), 1467-1478.

Tung, H., \& Chang, Y. (2011). Effects of empowering leadership on performance in management team: Mediating effects of knowledge sharing and team cohesion. Journal of Chinese Human Resource Management, 2(1), 43-60.

Yoo, W-S., Suh, K-S., \& Lee, M-B. (2002). Exploring factors enhancing member participation in virtual communities. Journal of Global Information Management, 10(3), 55-71.

Yukl, G., \& Fu, P.P. (1999). Determinants of delegation and consultation by managers. Journal of Organizational Behavior, 20(2), 219-232.

Zhang, X. M., \& Bartol, K. M. (2010). Linking empowering leadership and employee creativity: the influence of psychological empowerment, intrinsic motivation, and creative process engagement. Academy of Management Journal, 53(1), 107-128.

Wageman, R. (1995). Interdependence and group effectiveness. Administrative Science Quarterly, 40(1), 145-180.

Wang, S., \& Noe, H. (2010). Factors influencing knowledge sharing behavior. Service Science, 6(2), 51-71. 